\title{
Raising the Quality of Secondary Education in East Asia
}

\author{
Kaoru Nabeshima \\ DECRG \\ The World Bank
}

World Bank Policy Research Working Paper 3140, September 2003

The Policy Research Working Paper Series disseminates the findings of work in progress to encourage the exchange of ideas about development issues. An objective of the series is to get the findings out quickly, even if the presentations are less than fully polished. The papers carry the names of the authors and should be cited accordingly. The findings, interpretations, and conclusions expressed in this paper are entirely those of the authors. They do not necessarily represent the view of the World Bank, its Executive Directors, or the countries they represent. Policy Research Working Papers are available online at http://econ.worldbank.org.

\footnotetext{
* This paper was originally prepared as a background paper for "Innovative East Asia: The Future of Growth." The author thanks Shahid Yusuf, Simon Evenett, Chris Thomas, Louis Benveniste, and staffs from Human Development Network for their very useful suggestions and comments.
} 


\begin{abstract}
This paper seeks to advance our understanding of the determinants of student achievement among East Asian economies utilizing the TIMSS-R data set and in the process, to remedy some of the ambiguities in the literature to date.. These ambiguities are frequently due to the sparseness of detailed data on students, teachers, and schools. The TIMSS-R data set offers detailed information on these variables which is not typically available from other sources allowing us to isolate the impact of various factors affecting student achievement while controlling for specific characteristics of the students, teachers, and schools surveyed. Our results indicate that the most consistent factors affecting student performance are characteristics associated with students (innate abilities and home resources). Moreover, we do not find any consistent relationship between the performance of students and school resources or teacher autonomy, both of which are often advocated in the discussion of education reform.
\end{abstract}




\section{Introduction}

The importance of education to economic growth is well documented in the literature. The success of East Asia during its high growth period was underpinned by the rapidly expanding educational opportunities for its people, especially in secondary education (World Bank 1993). ${ }^{1}$ Analysis of export performance has placed considerable weight on the average years of schooling of labor force in East Asia (Chuang 2000; Witte 2000; Wood and Berge 1997). Compared to other developing regions, East Asia has attained a much higher enrollment rate, especially for secondary education.

By 1999, gross enrollment rates for economies in East Asia were close to universal coverage, although there is still a large variation within the region. While Japan and Korea achieved universal enrollment in 1999, other economies are lagging behind, especially in Indonesia, where only $55 \%$ of students in the relevant age group were enrolled in secondary education. Even though they are still behind and much improvement in enrollment is desirable, these economies have made steps towards increasing enrollment rates (see Table 1). ${ }^{2}$ At the same time, education quality measured by international test scores varies widely among these economies. Consequently, these economies need to pay closer attention to the quality of the education system in order to renew future growth.

\footnotetext{
${ }^{1}$ Even though the empirical evidence of returns to education in microeconomic literature is well-established (see, for instance, Harmon, Oosterbeek, and Walker (2003)), the results from macroeconomic literature is mixed. For instance, Prichett (2001) notes that the stock of human capital does not explain growth and Bils and Klenow (2000) find little evidence that initial schooling affects growth significantly. However, subsequent literature has reconciled the different finding in micro and macro literature by incorporating institutional differences (Chuang 2000), quality of education (Hanushek and Kimko 2000; Dessus 2001) and by using better data sets (de la Fuente and Doménech 2002; Krueger and Lindahl 1999; Krueger and Lindahl 2001). See Sianesi and van Reenen for a recent survey (2003). In addition, readers should bear in mind that changes in education systems take time to influence economic growth (Hanushek 2002).

${ }^{2}$ For instance, Thailand has greatly expanded its enrollment in recent years by increasing the number of lower secondary schools from 5,661 to 7,991 and the number of upper secondary schools from 2,041 to 2,817 between 1995 and 1996 (UNESCO 2001). This led to the increase in the gross enrollment rate of 59\% in 1997 to $79 \%$ in 1999 (World Bank 2002). Furthermore, compulsory education is now extended from six to nine years and the government guaranteeing twelve years of free education through the National Education Act of 1999 (Thailand Ministry of Education 2000). This effort is backed by allocating $20 \%$ of GDP to education, a number comparable to spending by Korea (World Bank 2000).
} 
In terms of the quality of education measured by the TIMSS-R results, ${ }^{3}$ economies in East Asia fare well compared to other countries that participated in TIMSS-R. Singapore, Korea, Taiwan, Hong Kong, and Japan rank among top five in math out of 38 countries who participated (See Table 2). Malaysia follows these five high performing countries, scoring above the United States. Thailand scored a little lower than the international average, while Indonesia and the Philippines scored substantially lower than the international average. In science, Taiwan scored the highest, closely followed by Singapore, then Japan and Korea. The only economy that fell from the top five spot is Hong Kong, which ranks $15^{\text {th }}$ in science. Similar to the results from math scores, the relative rankings of Malaysia, Thailand, Indonesia, and the Philippines stay the same (See Table 3). Thus, we have five relatively high scoring economies (Hong Kong, Japan, Korea, Singapore, and Taiwan), with others struggling to reach the international average (Thailand, Indonesia, and Philippines). Malaysia seems to be in the middle, trying to make it closer to the top performing economies. Since it is often advocated that strong math and science education is required for sustained economic growth, these countries lagging behind in terms of students' achievements in math and science (Malaysia, Thailand, Indonesia, and Philippines), it is quite important to disentangle the determinants of high achievement elsewhere.

This paper seeks to advance our understanding of the potential determinants of higher achievement among students in East Asian economies utilizing the TIMSS-R data set. The TIMSS-R data set offers detailed information on students, teachers, and schools, which is not typically available from other sources. This allows us to gauge the impact of difference in the teaching practices and effects of teacher autonomy among these economies in terms of test scores. In the next section, we lay down the basic empirical strategy. Section III then discuss the empirical results using the TIMSS-R data, and section IV concludes with policy implications for these economies.

\section{Prior Literature}

\footnotetext{
${ }^{3}$ Hanushek, Rivkin, and Taylor find that high test scores lead to continuation of studies (1996).
} 
Most studies on the determinants of educational outcome take the test scores as the measurable outcome of schools. ${ }^{4}$ Policy sets can be classified into two broad categories: policies on school resources and on the school systems. ${ }^{5}$ Under the umbrella of school resources, researchers consider classroom size, teacher qualification and experience, teacher training, and other aspects of physical resources at schools. The focus of studies on school systems is the organizational aspects of the educational system, namely the degree of competition allowed and of autonomy of each school.

The relationship between school resources and students' achievements has been examined quite intensively in the literature without clear answers. In much of the debate on the school resources, the most attention is given to class size. ${ }^{6}$ The proponents of smaller class sizes argue that this will lead to improvements in students' achievements, ${ }^{7}$ while critics question the validity of such argument. ${ }^{8}$ The empirical results on the effect of class sizes to students' achievements are mixed, reflecting the endogeneity and missing variable problems. Since placement of students in smaller classes can be potentially influenced by teachers and parents, the causality link cannot be estimated precisely unless data is generated from controlled experiment or other exogenous variations in class sizes are used as an instruments. Even when using such instruments, the results are varied. For instance, class size does not have any effect on students' achievements when using the population variation as the instruments (Hoxby $2000 \mathrm{~b}$ ) or the effect of class sizes flips signs when using a detailed data set to control for between and within school sorting (Woessmann and West 2002). In contrast, using exogenous variations in class sizes stemming from Maimonides' rule, Angrist and Lavy (1999) find that

\footnotetext{
${ }^{4}$ There are other possible indicators such as wages earned in later periods, continuation of education, and possibly other social outcomes often neglected by economists.

${ }^{5}$ Needless to say that student characteristics including family characteristics often exert large influence on students' achievements. However, in this section, we concentrate our discussion on factors that policymakers can readily influence.

${ }^{6}$ This may be the reflection that much of this debate stems from the U.S. experience, where basic infrastructure is already provided. For developing countries, this may not be case and the more resources allocated to schools, the more the student achievement may improve. For instance, a survey of schools in Jakarta reveals that many schools, especially private schools, lacked libraries and science labs (Behrman, Deolalikar, and Soon 2002). Another study on Indonesia shows that an increase in school funds leads to improvement in students' achievement (James, King, and Suryadi 1996).

${ }^{7}$ See for instance, Lee and Barro (1997), Krueger (2003).

${ }^{8}$ For instance, see Hanushek (1986; 2003).
} 
smaller class sizes do improve students test scores in Israel. ${ }^{9}$ Results from controlled experiments such as the Tennessee Student-Teacher Achievement Ratio (STAR) suggest that smaller class size may be beneficial to at least some students in improving their test scores (Krueger 1999). Furthermore, by improving the scores, students may decide to stay longer in school. Dustmann, Raja, and Soest (2002) find that students in smaller classes tend to stay in school beyond the minimum requirement using detailed student data in England and Wales. By continuing their studies, these students are also able to earn significantly higher wages later on.

Along with smaller class size, hiring and retaining quality teachers has been advocated to improve students' achievements over time. ${ }^{10,11}$ To achieve this goal, teachers' pay must be competitive to those possessing similar qualifications in other occupations in which they can choose. In the United States, the relative wages of teachers have been declining over the years. This decline in relative teachers pay is partly attributed to the growing opportunities available for women in the workplace. In the past, when occupations were segregated along gender lines, women had limited career choices. However, when alternative occupations began to materialize, many highly qualified teachers and potential teachers were able to choose these occupations rather than teaching. Temin (2002) shows that in the U.S., relative to teaching, other occupations offer as much as a $40 \%$ premium for similar qualifications. In this regard, East Asian economies seem to offer more generous wages to teachers (see Table 6). ${ }^{12}$

Empirical evidence does not offer clear links between teachers' compensation and student achievement. For instance, Hanushek, Kain, and Rivkin (1999) do not find any

\footnotetext{
${ }^{9}$ Following the Maimonides' Rule, the maximum allowed class size in Israel is 40 students. Thus, if there are 80 students in a grade, there would be two classes of 40 students each. However, if there are 81 students, there would be three classes with 27 students each.

${ }^{10}$ The current sentiment in the United States is that the teacher quality is relatively low compared to the past and to other professions. Lakdawalla (2001) finds that relative human capital possessed by teachers has been declining throughout the $20^{\text {th }}$ century, mainly due to skill-biased technological change outside of the teaching profession. This decline is most striking for primary school teachers where general knowledge is taught. For instance, teachers born around the beginning of $20^{\text {th }}$ century received six more years of schooling compared to those outside of the teaching profession. By 1950, teachers received only two to three more years of schooling. This downward trend is significant for both male and female teachers in both public and private schools.

Strauss and others (2000) find that average SAT scores of those who intend to pursue an education major is around the 35th percentile in Pennsylvania. In addition, the passing scores for standardized tests in Pennsylvania and other states which use the same test as part of certification requirement, is around the 25 th percentile. Because of this low requirement, the passing rate is better than $95 \%$ for all the applicants (Strauss and others 2000).

${ }^{11}$ A study by Angrist (2001) finds that in-service training leads to better student performance, pointing towards the importance of providing in-service training for teachers to keep their skills fresh.

${ }^{12}$ Nonetheless, the perception in Korea is that teaching is no longer considered to be a top occupational choice by Koreans and the quality of teachers is slipping in recent years ("South Korea: Leaving Home" 2001).
} 
relationship between teacher salaries and student achievement. They find that teachers weigh other factors, namely the quality of students much more in making their mobility decisions. On the other hand, Loeb and Page (2000) find positive and significant effects from higher wages.

Furthermore, schools seem to have difficult times retaining such qualified teachers once they are hired and the reason why many teachers leave the teaching profession continues to be debated. A study by Stinebrickner (2002) shows that for young, female teachers, the decision has more to do with childbearing and family raising than the prospect of a better job. In fact, he finds that half of the teachers who switch jobs earned less than what they were making previously. Thus, it is not the prospects of higher wages elsewhere per se that is influencing the career moves by teachers, but other factors. However, he also finds that higher wages can slow the exit rate from teaching of these young, female teachers, as they enable individuals to pay for daycare services.

Finally, performance-based incentives for teachers have been suggested to reduce attrition. However, this approach faces a number of obstacles. The first obstacle is how to measure the output of the teachers. Solely basing the decision on easily observable achievements such as test scores can lead to "teaching to the test" kind of behavior without improvements in teaching styles (Jacob 2002; Glewwe, Ilias, and Kremer 2003). ${ }^{13}$ In addition, students' overall performance is not determined by a single teacher, but by many teachers in different subjects. Nonetheless, private schools in the United States are using merit pay routinely, suggesting that the merit pay system has some utilities in the education sector (Ballou 2001). In fact, Lavy (2003) finds that incentive pay for teachers leads to improvement in students' performance in Israel.

Introducing market mechanisms to the school system, namely introducing competitive pressure so that these schools will improve, has been advocated for quite some time. ${ }^{14}$ Competition would allow students to choose among existing private and public schools and this choice by students would induce schools to improve their qualities. ${ }^{15}$ Experience from the United

\footnotetext{
${ }^{13}$ Or even worse, teachers (or schools) may encourage cheating to make sure that their students achieve the desired objected imposed on the school. Even though such cheating occurs rarely (2-3\% in the case of public school system in Chicago), "teaching to test" is though to be more wide-spread (Jacob and Levitt 2003).

${ }^{14}$ See Dolton (2003) on the discussion of the history of school choice.

${ }^{15}$ Benchmarks would be needed to enable families, administrators, and public officials to evaluate the performance of both teachers and schools. The benchmarks would have to address many dimensions of performance if they are to inform parents who decides which schools to send their children and administrators who hire/fire teachers.
} 
States suggests that competition between public and private schools (or charter schools) offering similar types of secondary education enhances student achievement and induces a shift away from private school attendance (Hoxby 2000a; Holmes, DeSimone, and Rupp 2003); it also improves teacher quality in public schools (Hanushek and Rivkin 2001). Similarly in the United Kingdom, after the introduction of school choice (among other reform initiatives), student achievement improved dramatically without increasing the level of education spending (Glennerster 2002). Finally, the Shinagawa Board of Education in Tokyo introduced the school choice system for public elementary schools in April 2000 and has plans to expand it to lower secondary schools (Muta 2000). ${ }^{16}$ However, similar to the debate on other education policies, the positive effects of school choice is not clear cut. For instance, Krueger and Zhu (2002) do not find statistically significant effect of vouchers in New York and Eberts and Hollenbeck (2002) find that students in charter schools in Michigan actually perform worse than those in public schools.

The competition facing public schools is more intense in the presence of established private schools. ${ }^{17}$ Under such circumstances, public schools must be granted some freedom in order to differentiate themselves from others. Otherwise, public schools may face difficult times attracting good students and teachers, which leads to the decentralization of the education system. ${ }^{18}$

The motivation behind the decentralization is the belief that schools could and would customize their curricula based on the local needs and this leads to the improvements in students'

\footnotetext{
${ }^{16}$ Since upper secondary schooling in Japan is not compulsory, there is a significant degree of competition and sorting among schools, especially in urban areas.

${ }^{17}$ Care must be given to the distinction between private and public schools. For example, although private upper secondary schools in Korea are well established, they are not private schools in the usual sense. Decisions on curriculum and tuition are made by the government, and the allocation of students is randomized across public and private schools. As a result, competition between schools is nonexistent. Lee (2001) views this lack of competition as one of the factors contributing to the poor performance of upper secondary education in Korea. Furthermore, we implicitly assume that private schools perform better than public schools. While this is generally the case, private schools in Indonesia perform worse (Behrman, Deolalikar, and Soon 2002). See Benveniste, Carnoy, and Rothstein (2003) for the discussion on the difference between public and private schools in similar socio-economic environment.

${ }^{18}$ Using data from the Milwaukee Parental Choice Program in the United States, Rouse (1998) finds a modest increase in the performance of students who participated in the program compared to students who did not. Similarly, Angrist and others (2002) find positive effects of vouchers in Columbia. However, Levin (1998) questions whether voucher systems are more efficient and equitable than the current U.S. system. Some governments may choose to provide direct support to families, supplying funds to use at the secondary schools of their choice in order to alleviate equity concerns.
} 
achievements. Some form of decentralization is necessary especially when competition is introduced among schools so that each school can differentiate itself from others to attract teachers and students. Decentralization clearly poses complex issues regarding which responsibilities to be delegated to the local level and which to be retained by central authority. ${ }^{19}$

The current state of thinking on this subject is that teachers should be granted more autonomy in the classroom and in their choice of teaching materials and course contents, but that teacher autonomy is not sufficient by itself. It should be accompanied by decentralization of authority allowing individual secondary schools to hire and promote teachers and determine compensation to some extent, so as to attract the most talented teachers. Decentralization involves moving away from tight controls by central, regional, or local authorities over the employment conditions of teachers. To be sure, these authorities retain an interest in ensuring that certain minimum standards are met. ${ }^{20}$ Nevertheless, the tendency to micro-manage school staffing and class content should be avoided. ${ }^{21}$

Most empirical studies regarding the effectiveness of decentralization are from Latin American countries where decentralization of education has been actively pursued since the 1990s. ${ }^{22}$ Jiménez and Sawada (2001) find that decentralization in El Salvador led to improvements in language skills and a reduction in student absences, primarily by making schools more accountable to local communities. Eskeland and Filmer (2002), investigating the effects of decentralization in Argentina, find that more school autonomy is closely related to higher student achievement. There are a number of studies on decentralization in Chile, where the implementation of decentralization is widely viewed as successful (see Parry (1997); Vegas (2002)).

However, the degree of improvement expected in the students' achievements thus far has not been realized. One reason could be that the introduction of decentralization policies do not necessarily lead to implementation, as pointed out by King, Ozler, and Rawlings (1999). Another

\footnotetext{
${ }^{19}$ Existing research suggests that decentralization of finance typically increases inequity in both access to and quality of education (Glewwe 2002).

${ }^{20}$ For instance, countries can offer national tests to assess student achievement, as implemented in the Philippines (National Secondary Achievement Test) and in Korea (National Assessment of Scholastic Achievement). In terms of school quality, the Office for National Education Standards in Thailand goes so far as to evaluate every school and to publicize the ratings (UNESCO 2001).

21 Chapman (2000) discusses the effects of decentralization on quality of education, and Woessmann (2001) examines the relationship between institutional arrangements and student achievement.

${ }^{22}$ For the effect of fiscal decentralization in the Philippines, see Behrman, Deolalikar, and Soon (2002).
} 
confounding issue is that decentralization is often introduced for political rather than educational reasons. In such cases, it is not surprising that there is little change in the learning environment. Moreover, shifting authority and responsibilities to local school administrators with inadequate experience and training will not yield the intended results. In her analysis of Thai educational reforms after the financial crisis, Witte (2000) speculates that the desire to build consensus around national educational policy initiatives came at the price of vagueness, which allowed teachers and officials to interpret rules as they like. In Hong Kong, the government announced the School Management Initiative, which resembles school-based management in the United States in 1991 (Dimmock and Walker 1998). Despite some evidence that standards of teaching have improved and teachers have more flexibility in their use of resources following decentralization, student scores have not improved.

\section{Empirical approach}

As is conventional in much of the empirical literature on the economics of education, we adopt the production function approach with:

$$
\text { Score }=f(X)
$$

Where Score is measured by TIMSS-R scores which proxies for the quality of education as typically used in the literature. $X$ typically includes school resource variables (class size, perstudent spending, teacher qualification, teacher wages) and demographic variables. Following this, we utilize the detailed data obtained by TIMSS-R.

$$
\text { Score }_{j k l i}=f\left(S_{i}, P_{i}, C_{j}, T_{k}, X_{l}, D_{l}\right)
$$

Where Score $_{i j k l}$ is measured by TIMSS scores in math and general science for student $i$ in class $j$ taught by teacher $k$ in school $l$. $S_{i}$ includes student characteristics (innate ability, motivation, and gender), $P_{i}$ includes parents' characteristics of student $i$ (education attained by father and mother, degree of academic excellence emphasized by mother, home resources, and family structure). $C_{j}$ specifies the peer effect by classmates (the perceived importance of 
math/science achievement by classmates, average educational level of parents in class) and class size. $T_{k}$ includes the teacher characteristics such as teacher qualification, age, gender, experience, and teaching methods for teacher $k$. $X_{l}$ includes principals' report on facilities adequacy at school $l$. $D_{l}$ includes a set of variables indicating the degree of decentralization at school $l$.

Most empirical studies of education are concerned with endogeneity issues. This is especially true in the Untied States where parents make residential decisions partially based on the quality of schools available in a community. Since high quality schools are much sought after, this demand is reflected in the higher prices for homes. Thus, it is hard to separate whether students are doing well in school because of the quality of local education or because of the high income of parents. Thus, estimates from equation 1 are biased upward if these endogeneity problems are not taken into consideration. Much of this bias can be accounted for by including detailed characteristics that may influence the educational achievement of students. Unlike other data sets in which students and parental information are missing, TIMSS-R offers a rich set of data on them. Including these variables in the specification enables us to alleviate the bias problem.

\section{Variables}

Among the possible determinants of student achievement, family resources are thought to exert a large influence (see for instance Hanushek and Luque (2002)). Typically in the literature, this is proxied by the educational level attained by parents. From the TIMSS-R data set, we observe that the higher the parents' education level, the higher the scores for both math and science in East Asia. ${ }^{23}$ However, parents' education is just a proxy to gauge students' educational environment at home. For example, parents in Korea spend as much as 25 percent of their income to support their children's education through supplementary materials and private tutoring (Lee 2001). To better judge the effect of the availability of such home resources, one needs to include other information in addition to parents' education. TIMSS-R offers rich survey data on this, and we include variables, home_high and home_low. The measure of the home

\footnotetext{
${ }^{23}$ In addition, the higher the parents' education, the more students aspire to finish a university degree, except for in Indonesia and in Thailand where the majority of $8^{\text {th }}$ graders plan to finish university education regardless of their parents' education. On the other hand a much higher proportion of $8^{\text {th }}$ grade students in Singapore and Taiwan plan to pursue vocational training rather than university. Students from Korea seem to have the highest aspirations.
} 
resource includes parents' education, number of books at home, and availability of calculators, dictionaries and other study-aid materials. Casual inspection of the data reveals that the home resources are positively correlated with student achievement (See Table 4).

We use two variables to control for the student specific characteristics. One is the sex of the students and the other is a control for the student's innate ability. This is another variable that is often missing in most studies on education. Without this variable, it is hard to separate the effect of school on students. One never knows if it is the good school that makes students perform better or these students who are better equipped to the educational challenge attend good schools. In an ideal situation, we would like to obtain the past performance measure of students to control for their innate abilities. However, lacking such data, the best indication of their innate ability is their subjective assessment of how well they understand math and science in general. We use a dummy, mgood (sgood) for those students who responded that they do well in math (science) in general. Information on parents and students are used primarily as controls. In terms of policy implications, we are interested in possible levers that policymakers can pull to improve students' achievements. One type of such levers is school resources.

Class sizes in East Asia tend to be on the larger side compared to the international average and to the United States. Those who perform better than others tend to have class sizes lower than 40, except for Korea, although variation among these countries are small. ${ }^{24}$ Those countries scoring lower than the top five economies, Indonesia, Philippines, and Thailand have much larger class sizes (See Table 5). Therefore, looking cross-country among these economies, smaller class sizes seem to be associated with higher achievement. To test this, we include class in the regression. However, compared to the international average, these economies still have larger class sizes. Thus, correlation of class size to student achievement needs to be evaluated with care. Along with the class size variable, we also include a set of variables representing the adequacy of school infrastructure reported by the principals to test the effect of school resources other than classroom size.

Another issue is the quality of teachers. In terms of percentage of students taught by qualified teachers, East Asian economies fare pretty favorably compared to the international

\footnotetext{
${ }^{24}$ In Japan, allocation of teachers is done by using a simple method of dividing the student size by 40 . Thus, the maximum number of students in each class is limited to 40 students. It is curious to note that this is similar to Maimonides' rule in determining the class size.
} 
average and to the United States. Except in Hong Kong, Malaysia, and Thailand, more students in East Asia are taught by well-qualified teachers in math than the international average. In science, fewer students in Indonesia, Malaysia, Philippines, and Thailand are taught by qualified teachers compared to the international average (See Table 7). This mirrors quite closely their relative rankings in TIMSS, except for Hong Kong. In terms of certification of teachers, except for Indonesia in math, close to all students in these economies are taught by certified teachers. One puzzling picture from this table is the low percentage of students in math class taught by certified teachers in Indonesia, whereas almost all students in science classes in Indonesia are taught by certified teachers. For these economies, it seems that improvements in teacher training in the relevant subjects that they teach may be warranted. Of course, this is assuming that students who are taught by qualified teachers outperform others. We used mqua (squa) as the measure for the teacher quality in math (science). We use qualification rather than the certification as the observable quality of teachers. The choice is mainly due to the low variance of certified teachers in most countries. Also it may be the case that certification itself may not be a guarantee of quality (see (Angrist and Guryan 2003)). To check whether incentive mechanisms have any discernable influence on students' achievements, we include salaries and hiring, dummies indicating that hiring and salaries decisions are made at the school level.

In terms of the institutional setting of the school system, we need to include variables representing the degree of competition and autonomy among schools in East Asia. The data set provided by TIMSS-R is silent on the issue of competition. However, one might be able to proxy the degree of potential competition by the geographical location of schools. That is, schools in cities will tend to face much severer competitive pressures from not only other public schools, but also from private schools, whereas in the "isolated" areas such pressure would be much less. Thus we include two location dummies, city and isolated, with rural as the base case. $^{25}$

In this paper, we focus our attention on teacher autonomy which is typically a part of decentralization effort. The transmission mechanism should be teacher autonomy which should

\footnotetext{
${ }^{25}$ The existence of private schools may confer other benefits also. Typically private schools are thought be more efficient in managing the school resources relative to publicly managed schools. Such is the case for Indonesia (James, King, and Suryadi 1996). Expenditure per pupil is 40\% lower in Korea (OECD 1998) and 25-30\% lower in Thailand (World Bank 2000). In addition, adults who attended private institutions in the past tend to earn higher wages in Indonesia, even after correcting for selection bias (Bedi and Garg 2000).
} 
correspond to differences in teaching methods that would result in differentiated achievements among students. As a measure of autonomy enjoyed by teachers, we construct a set of dummy variables based on two questions on teacher's survey: the freedom to choose textbooks and contents to be taught. auto1 is a dummy variable for "cannot choose textbook but content", auto2 is for "can choose textbook but not content", and auto3 is for "can choose textbook and content". The baseline is no autonomy. Also we include sets of interactive dummies between autonomy and salaries and hiring to test whether incentive mechanisms work well with teacher autonomy.

\section{Results}

\section{Math}

Table 8 and 9 list the regression results from the full specification. Regression results on own ability/aspiration and home resources are the most consistent results obtained from various different specification. The indicators of self-assessment ("usually does well in math" (mgood), and "has good understanding of math" (bsdmcmai)) are positive and significant with large magnitude. The only exception is the estimates for students in Indonesia. Their self-assessment measured by mgood do not corresponds well to higher scores. Given that students who have good understanding of math still do well relative to others, it may be the case that math classes in Indonesia may be less challenging compared to other countries, where students need to have good understanding of math to do well in their countries. It seems that students without good understanding of math can still do well in Indonesia.

Positive attitudes towards math (bsdmpatm) also seem to have positive effect on the scores. Except for students in Korea and Singapore, where positive attitudes have no statistically significant effect and in the U.S., where positive attitudes actually have a statistically negative effect. Self-aspiration (bsbgedse) is also associated with higher scores, except for Singapore in science. Quite naturally, if one is interested in the given subjects, we can safely assume that they exert more efforts towards understanding these subjects.

As expected, those with high home resources perform well, while those with low home resources perform much worse in general. Although in Hong Kong, the Philippines, and Singapore, home resources do not have any statistically significant effects on either variables and high home resources in Indonesia do not have any statistically significant effect. There is a 
considerable variance to the magnitude of the coefficients among economies in East Asia, varying from 36 to 57 points difference between students with low and high home resources and the U.S. exhibiting the largest difference of 63 points. The data on parental education in Japan is not reported, hence the omission of home resource variables for Japan.

Most studies find family factors to be an important determinant of students' performance. In contrast, we find no significant effects in Hong Kong, Philippines, and Singapore. It may be the case that these school systems are more equitable in a sense that their schools enable students from differing background to perform well. On the other hand, the results on Indonesia may indicate that schools in Indonesia may not be preparing students well, given that students with low home resources perform relatively worse, yet students with high home resources do not do better either. Coupled with the previous findings that even those students who may not have a good understanding of math can still do well in Indonesia, quality of math classes needs to be improved in Indonesia.

On the gender, there is no clear pattern across countries. In Hong Kong, Indonesia, Thailand, and the U.S., boys do better than girls (5-14 points). On the other hand, in Japan, Korea, and Singapore, boys do worse than girls by 5-7 points. In Malaysia, the Philippines, and Taiwan, there is no statistical difference between performance of boys and girls.

Competition proxied by geographical location seems to matter, as we would expect. Those who are in cities score higher, especially in Indonesia and the Philippines. The exceptions are the result of the U.S. where students in cities score lower, and in Japan, where their scores do not differ from those from rural area. ${ }^{26}$

Surprisingly, the results from the teacher qualification are quite mixed. We obtain expected results in Hong Kong, Japan, Korea, and Singapore, but results from the Philippines and Taiwan are both negative and significant, and results from Indonesia, Malaysia, and Thailand are insignificant. For Indonesia and Thailand, inclusion of interactive dummies

\footnotetext{
${ }^{26} \mathrm{We}$ also included variables measuring the adequacy of infrastructure reported by the principal and an indicator of "good" schools (meaning less disciplinary action required). The results on the infrastructure was mixed. One would expect that lack of physical infrastructure, especially at the lower income level, will have a negative influence on students' achievement. However, the result mirrors that of the class size. That is, the more principals are concerned about the physical infrastructure of the school, the better the students perform. This may arise from the subjective nature of the question. Good schools with higher aspiration may consider the current physical infrastructure of schools to be inadequate for the future, thus expressing greater dissatisfaction with the facility even though it may be quite sufficient compared to other schools. The results on the measure of "good" school is as expected. The less that the school needs to deal with disciplinary measures, the better the students perform.
} 
between hiring/salaries and teacher autonomy resulted in the coefficients on teacher qualification to switch from being positive and significant to insignificant, while for Malaysia, the coefficients on teacher qualification are insignificant among different specifications.

The results on class size are also mixed. For students in Hong Kong, Malaysia, Thailand, and Taiwan, smaller class sizes are more beneficial. On the other hand, larger class sizes are more beneficial for Indonesia, the Philippines, Singapore, and the U.S. This is quite odd in that class sizes in Indonesia and the Philippines are among the largest in East Asia. This may reflect a couple of potential endogeneity problems such as: more able students are put into a larger class (struggling students are put into a smaller class), ${ }^{27}$ more able students are put into a larger class, face more competition, and therefore do better; students develop more initiative and self-reliance in a larger class room setting, and this leads to better performance; better teachers are assigned to larger classes (so larger class is a proxy for teacher quality) (Dolton and Vignoles 2000). However, as explained the earlier section, we control for the student's ability and teacher's qualification, which should mitigate such endogeneity problems. Hence, it is rather hard to explain the counterintuitive results based on such arguments. In addition, the results on the classroom size are fairly stable across different specifications. Thus, we are still left with mixed results on the effect of class size reflecting the current debate in the literature.

The results on the teacher autonomy vary widely among different countries. One would expect that as teachers gain more autonomy, they should be able to adopt teaching methods most conducive to improving students' achievements. However, the results from the regression do not provide a clear-cut picture that such a prior is correct. In terms of hiring and salary setting practices of the schools, most results are insignificant or of wrong signs. For hiring, the coefficients are negative in Hong Kong, the Philippines, and the U.S. and for salaries, in Indonesia, Korea, Thailand, Taiwan, and the U.S. Only in Indonesia, hiring affects the student performance positively and salaries having positive effects in Hong Kong, Malaysia, and the Philippines. Thus, we do not find any clear results from teacher autonomy and related incentive mechanisms.

\footnotetext{
${ }^{27}$ West and Woessmann (2003) finds that students tend to be sorted into classes with different sizes. Among the 18 economies they consider, Hong Kong, Japan, Korea, and Singapore were included with all but Korea exhibiting sorting behavior. However, much of this sorting occurs between schools (i.e. parents choose schools with smaller class sizes), rather than within school sorting (i.e. teachers and/or administrators place poor performing students in smaller (or larger) classes), except in Singapore where students are sorted in both respects. Our results on Hong Kong and Singapore conform with the findings by West and Woessmann, but not for Japan and Korea.
} 


\section{Science}

The indicators of self-assessment ("usually does well in science" (sgood)) are positive and significant with large magnitudes, except for results for Indonesia, Philippines, and Thailand. On the other hand, students who claim they have good understanding of science (bsdscmai) do well in all countries considered. Again, results in Indonesia mirror those of math. Indonesian students who do well usually in Indonesia do not score any higher, but those who have good understanding still score higher relative to others. It is quite interesting to note that when one rank countries based on coefficient estimates on sgood, one gets more or less the ranking of perceived technical strength of this group of countries. The only out-of-place countries are Korea and Japan relative to the United States. Positive attitudes towards science (bsdmpats) also seem to have positive effect on the scores. Self-aspiration (bsbgedse) is also associated with higher scores, except for Singapore.

In terms of the availability of home resources, ${ }^{28}$ a lack of them significantly negatively affects student performance in Korea, Malaysia, Taiwan, and the U.S., whereas students with low home resource in Singapore actually score higher. On the other hand, an abundance of resources is beneficial in Hong Kong, Korea, Malaysia, Thailand, Taiwan, and the U.S. Again, home resources do not seem to matter in Indonesia and the Philippines. These results are consistent with the findings from regressions on math. The gender difference is more pronounced in science than in math. Boys do significantly better in Hong Kong, Indonesia, Korea, Malaysia, Thailand, Taiwan, and the U.S. This gender difference is more pronounced than for the results on math. Schools located in cities do well in Malaysia, the Philippines, Thailand, and Taiwan. Similar to the results obtained in the math regression, schools in cities perform worse in Japan and in the U.S. ${ }^{29}$ However, overall results are weaker compared to the regression results from math.

As expected, results on class size are not clear-cut. Smaller classes seem to be beneficial in Hong Kong, Malaysia, Thailand and Taiwan. On the other hand, we still obtain positive and

\footnotetext{
${ }^{28} \mathrm{We}$ also control for parental pressures by including a variable measuring whether mothers think math (science) is important. From the results, a mother's influence seems to be important. The results on admission policies are mixed. From the TIMSS data set, it is impossible to identify which are private schools. The results on peer are quite contrary to the findings in the literature. The coefficient estimates on peer are mainly negative.

${ }^{29}$ The results on the adequacy of infrastructure and "good" school indicators are quite similar to the results obtained from the math regression.
} 
significant coefficients on class size for Indonesia, Japan, and Singapore. However, results on class size are at least consistent within a country.

The results on the teacher quality are more in line with our expectation, except in Singapore where it is negative and significant. For the other economies, the coefficient estimates are positive and significant in many economies, unlike much weaker results from the math regression. It may be the case that qualification in science is more closely associated with quality of teachers than in the case for math. This can be readily seen in Indonesia. The results on teacher qualification for math was not significant but for science, it is significant and large. Looking at teacher characteristics, most math teachers are qualified, but slightly less than half are certified. On the other hand, two thirds of science teachers are qualified, while almost all of them are certified. This implies that certification in Indonesia may not be a good indicator of quality of teachers. ${ }^{30}$

We also ran alternative specifications basing teacher qualification on the degree they received. Having teacher certification is associated with higher scores in Hong Kong, Indonesia, and Malaysia, and the Philippines in science. For the degree of the teacher in math, the results are mixed and no discernable pattern emerges comparing the results across countries. In science, students taught by teachers receiving a BA in science seem to perform better, while students taught by teachers with a BA in education actually perform worse than by teachers with a BA in other subjects. For teachers with an MA, results are mixed.

Again, the results on teacher autonomy vary across different countries. Only in a few instances such as in Malaysia and the Philippines do we obtain positive and significant results. For the all the other economies, the estimates are mostly negative or insignificant. The estimates on salaries are significant and positive in Malaysia, the Philippines, Taiwan, and the US. The estimates on hiring are significant and positive only in Thailand and the U.S.

\section{Discussion}

From the regression results and from the literature, there are only few observable variables that consistently predict the performance of students in terms of test scores. Naturally, the student's own ability (partly reflecting their past educational experience and partly reflecting

\footnotetext{
${ }^{30}$ Although it is curious why only half of math teachers are certified in Indonesia.
} 
their endowment) typically exerts a large influence on the future performance, and so do the home resources which are made available to students. We included these variables along with the aspiration mainly to control for the ability and effort level of students. Hence, very little policy prescriptions can be gleamed from these results.

For the other variables that policymakers can readily influence, the results are mixed at best. One of the main reasons why the issue of the class size is emphasized in the United States and elsewhere is the fact that this is one of the easiest attributes of the education system to change and implement. Similar to previous studies on this issue, our results on the class size are mixed, even though we controlled for many of the characteristics of students and parents that are not typically available in other studies. Two explanations can be offered for our results. The first is that class size dose matter for students' achievements. The other is that our results are still affected by endogeneity problems. The inclusion of these variables should mitigate the endogeneity problem associated with class size. Our results suggest that the use of more detailed data sets may not truly correct for the endogeneity issue. If that is the case, then the way to proceed in this regard is to utilize the controlled experiments. The results from these controlled experiments do show the beneficial effects arising from smaller class size, especially among those who are disadvantaged. Provided that these results are more robust than fragile findings from non-controlled data sets, we find smaller class sizes to be effective in some economies. Hence it may be worthwhile to consider moving more towards smaller class size. This may also be beneficial if teacher and student interactions are required in the future, a reflection on the criticism of rote learning in East Asia. However, caution must be paid in the actual feasibility of implementing a system-wide reduction in class sizes. Since reductions in class sizes typically lead to a larger number of teachers, ${ }^{31}$ policymakers need to assess the increase in the demand for teachers and adequate supply of qualified teachers. The evidence from the system-wide class size reduction in California points out the danger that such sudden reduction in class size can lead to reallocation of teachers within the state, resulting in better teachers moving towards better schools, and poor performing schools are left to scramble to fill the vacancies. The end result of such movement of teachers is that poorer districts saw the reduction in teacher quality while better districts did not suffer as much (Jepsen and Rivkin 2002).

\footnotetext{
${ }^{31}$ This may not be the case for some economies which face rapid aging of population such as Japan.
} 
This leads to the question of the teacher qualification. Even though degrees granted to teachers do not necessary mean that these teachers are better than those without advance qualification, the results from the test scores on science clearly indicate that students who are taught by qualified science teachers perform much better. On the other hand, qualification does not seem to matter too much in mathematics. It may be the case that one needs more solid understandings of science matters to be able to teach, in addition to the fact that most natural science teachers also tend to have a solid understanding of math. Thus, improvements in science education and expansion in science enrollment at the tertiary level can assist producing more teachers with solid understanding of science in addition to help moving the economies towards an innovation-based growth strategy.

The results on teacher autonomy were quite disappointing. The expectation was that with autonomy, teachers would be able to tailor the classroom conduct for students, leading to higher students' achievements. That is, teacher autonomy leads to different teaching methods, which ultimately result in higher scores. However, teachers in East Asia do not seem to change the way they teach regardless of the degree of autonomy that were granted to them. Table 10 shows the count of teaching methods ( 25 different indicators) that differ from the base case (no autonomy) based on teachers' responses on their classroom conduct in TIMSS-R. Out of 25 different indicators at most three are different compared to the base case in math. In science, teachers in the U.S. with full autonomy have seven indicators different from the base case, but otherwise, at most three. Looking at this table, it is hard to believe that autonomy has changed the teacher conducts in the class across countries. Without differing teaching conduct in the classroom, one would not expect teacher autonomy would lead to higher student achievement.

Then, the question is why teachers in East Asia do not change their teaching methods even though they are given the freedom to do so. They may lack knowledge about alternative teaching methods and materials. Teacher autonomy needs to be accompanied by proper training for both administrators and teachers if they are to achieve their intended goals (Chapman 2000). For instance, a new subject, "Integrated Learning" was introduced in Japan in 2002. Unlike in the past, the Ministry of Education, Culture, Sport, Science and Technology gave teachers greater latitude on what and how to teach such subjects. The only guideline issued by the Ministry was that these classes should be aimed to foster the ability to think, learn, and explore independently and creatively. However, after numerous requests from teachers, the Ministry at 
the end decided to circulate guidelines on how to teach such subjects, since many teachers and local school boards did not know how and what to teach such classes (Cave 2001; Muta 2000). Without such reform, teachers are likely to follow templates or frameworks laid down by authorities that may be either too rigid to allow autonomy or too vague to indicate priorities.

Furthermore, there may be a complex interplay among other factors that may affect the teacher's decision to alter his/her teaching practice. For instance, in Malaysia and the Philippines, the estimates on autonomy and salaries were both positive, and the results from Chile also suggest that autonomy, coupled with hiring decision, leads to higher student achievement, whereas autonomy itself does not (Vegas 2002). These results suggest that both autonomy and incentives given to teachers are important in improving student performance. Further research in this area would shed more light on what kind of mechanisms are most effective for changing teacher conduct in the classroom and improving student achievement. More broadly speaking, the complexity of education systems means that several factors, including teacher qualifications, community involvement, and school management, interact with one another to determine student achievement. Further research has been recommended to assess the kind of decentralization that would most effectively deliver the desired results (Glewwe 2002).

Overall, our approach to deepen the understanding of the education process yielded similar results to existing studies, despite the fact that we used a much richer dataset. Only in Malaysia did we consistently find expected results on teacher autonomy and incentive mechanisms. In other economies, the results are mostly counterintuitive, save for the most basic determinants such as family background and students' abilities. Even for these variables, estimates vary widely among the sample of countries. This suggest that each country's education process is quite diverse and the differences affect various factors in a nono-systematic way. Take Indonesia for example. From the regression results, we may infer that schools are less challenging in Indonesia, since students who usually do well in math and science do not score higher than those who don't, yet in other counties, those who do well in their countries also do well on TIMSS. But Indonesian students who have good understanding of science still did well on TIMSS, and effects on this are not that different from students from other countries. Inclusion of detailed characteristics on students, teachers, and schools still yields mixed results, except for students' innate abilities and home resources. This suggests that empirical strategy 
solely based on a richer dataset may not be a fruitful exercise. Instead, one needs to carefully evaluate what factors are truly exogenous and what factors are endogenous.

In order to do so, an empirical strategy based on experiments would be advisable. These experiments can be controlled such as Project STAR or natural experiments such as the exogenous changes in class size in Israel. However, questions still remain as to what extent results from such experiments can be transferred to other countries. Similar experiments across countries may be able to identify the feasibility of such changes. For the natural experiments, the occurrence of such events is fairly rare and it is up to the researchers to identify such events and be able to draw some policy suggestions. The study on Israel focused on exogenous changes in the class sizes caused by an explicit rule on the maximum class size. But it is not clear if there are such other examples on class sizes and whether one can conduct similar studies on other potential determinants.

\section{Conclusion}

Our results confirm the mixed findings on determinants of student achievement in the literature. The most consistent determinants are students' past achievements and educational resources available at home. In terms of teacher quality, teacher qualification in science is found to be an important determinant for higher achievement, whereas in math, teacher qualification

plays much smaller role. As for school resources, especially class size, the findings in this paper are mixed. For some students in some economies, smaller class sizes are beneficial, but not for others. This is despite the fact that we control for extensive sets of student, family, teacher, and school characteristics, which are often not available in other studies. Even results obtained from studies based on controlled experiments like Project STAR are not ironclad. The results may be more supportive of smaller classes, yet one may obtain such results from higher effort levels by those who are involved in the experiments (Hoxby 2000b). Studies based on exogenous variation in classrooms such as in Israel (Angrist and Lavy 1999) is quite illuminating, but we are not sure how many such exogenous changes can be readily identified. It may well be the case that what matters is the ability of teachers, rather than a simple reduction in class size (Woessmann and West 2002) or it may be influenced by peers (Fertig 2003; Lazear 2001). 
The finding on teacher autonomy was at odds with the prior belief that teacher autonomy would lead to better student performance. Further scrutiny of the data reveals that teachers do not always exercise their autonomy in East Asia. Thus, teachers with little to full autonomy teach the same way as teachers without any autonomy. It is no wonder that we did not detect any differences in students' achievements across teachers with varying degrees of autonomy.

This clearly illustrates the problem of isolating effects from a reform and the actual changes in the behavior of teachers. To better assess the benefits of teacher autonomy and decentralization, one needs to pay particular attention to what has actually changed in the classroom, rather than just testing the change in policy direction.

In general the empirical studies in education are hampered by lack of detailed comprehensive data on students, teachers, and schools. However, even utilizing such data, the results are still not clear-cut. The results from experiments provide us with much clearer picture of what kind of policies affect students' achievements and are empirically more robust than any analysis that is based on the observational data. However, such experiments are sparse, and more of these experiments are needed to judge the applicability of similar policies to other countries. Future research in this field can benefit tremendously from such efforts and this may be a more fruitful way to approach the quality of education rather than relying on the observational data. 
Table 1: Gross Enrollment Rate in East Asia

\begin{tabular}{ccccccc}
\hline & \multicolumn{2}{c}{ Primary } & \multicolumn{2}{c}{ Secondary } & \multicolumn{2}{c}{ Tertiary } \\
\hline Country & $\mathbf{1 9 8 0}$ & $\mathbf{1 9 9 9}$ & $\mathbf{1 9 8 0}$ & $\mathbf{1 9 9 9}$ & $\mathbf{1 9 8 0}$ & $\mathbf{1 9 9 9}$ \\
China & 113 & 106 & 46 & 63 & 2 & 7 \\
Hong Kong & 107 & $94^{\mathrm{a}}$ & 64 & $72^{\mathrm{a}}$ & 10 & $27^{\mathrm{b}}$ \\
Indonesia & 107 & 103 & 29 & 55 & 4 & $11^{\mathrm{b}}$ \\
Japan & 101 & 101 & 93 & 102 & 31 & 46 \\
Korea & 110 & 99 & 78 & 97 & 15 & 72 \\
Malaysia & 93 & 101 & 48 & 99 & 4 & 23 \\
Philippines & 112 & $113^{\mathrm{b}}$ & 64 & $76^{\mathrm{c}}$ & 24 & $29^{\mathrm{c}}$ \\
Singapore & 108 & 80 & 60 & $74^{\mathrm{a}}$ & 8 & $44^{\mathrm{b}}$ \\
Thailand & 99 & 94 & 29 & 79 & 15 & 32 \\
\hline
\end{tabular}

Note: a 1996 b 1997 c 1998

Source : WDI 2001 
Table 2: Mathematics Scores from TIMSS-R

\begin{tabular}{cccc}
\hline Country & Math score & Math rank & $\begin{array}{c}\text { Higher than international } \\
\text { average }\end{array}$ \\
\hline Singapore & 604 & 1 & YES \\
Korea & 587 & 2 & YES \\
Taiwan & 585 & 3 & YES \\
Hong Kong & 582 & 4 & YES \\
Japan & 579 & 5 & YES \\
Malaysia & 519 & 16 & YES \\
United States & 502 & 19 & YES \\
Thailand & 469 & 27 & \\
Indonesia & 403 & 34 & \\
Philippines & 345 & 36 & \\
International Average & 487 & & \\
\hline Note: Out of 38 countries who participated in TIMSS-R &
\end{tabular}


Table 3: Science Scores from TIMSS-R

\begin{tabular}{cccc}
\hline Country & Science score & Science rank & $\begin{array}{c}\text { higher than international } \\
\text { average? }\end{array}$ \\
\hline Taiwan & 569 & 1 & YES \\
Singapore & 568 & 2 & YES \\
Japan & 550 & 4 & YES \\
Korea & 549 & 5 & YES \\
Hong Kong & 530 & 15 & YES \\
United States & 515 & 18 & YES \\
Malaysia & 492 & 22 & YES \\
Thailand & 482 & 24 & \\
Indonesia & 435 & 32 & \\
Philippines & 345 & 36 & \\
International & 488 & & \\
average & & & \\
\hline
\end{tabular}

Note: Out of 38 countries that participated in TIMSS-R 
Table 4: Home Resources

\begin{tabular}{|c|c|c|c|c|c|c|}
\hline \multicolumn{7}{|c|}{ Home Resources } \\
\hline Math & Low & Medium & High & & Median & \\
\hline HK & 18.68 & 78.15 & 3.17 & 573.21 & 595.07 & 628.29 \\
\hline IDN & 42.68 & 56.41 & 0.91 & 372.38 & 417.34 & 524.49 \\
\hline KOR & 5.24 & 79.78 & 14.98 & 513.56 & 589.49 & 640.58 \\
\hline MYS & 23.88 & 70.88 & 5.24 & 481.29 & 531.29 & 603.01 \\
\hline PHL & 29.91 & 67.44 & 2.65 & 321.52 & 349.86 & 427.74 \\
\hline SGP & 2.69 & 92.23 & 5.08 & 580.87 & 580.81 & 611.28 \\
\hline THA & 48.23 & 49.74 & 2.03 & 446.91 & 484.29 & 568.22 \\
\hline TWN & 8.02 & 84.37 & 7.61 & 510.80 & 599.48 & 672.90 \\
\hline USA & 5.05 & 73.65 & 21.31 & 421.77 & 486.68 & 553.11 \\
\hline Science & Low & Medium & High & & Median & \\
\hline HK & 18.68 & 78.15 & 3.17 & 521.96 & 537.63 & 567.00 \\
\hline IDN & 42.68 & 56.41 & 0.91 & 424.12 & 449.55 & 507.93 \\
\hline KOR & 5.24 & 79.78 & 14.98 & 532.80 & 479.37 & 546.54 \\
\hline MYS & 23.88 & 70.88 & 5.24 & 460.96 & 501.09 & 573.18 \\
\hline PHL & 29.91 & 67.44 & 2.65 & 312.21 & 355.59 & 457.07 \\
\hline SGP & 2.69 & 92.23 & 5.08 & 531.80 & 511.76 & 517.18 \\
\hline THA & 48.23 & 49.74 & 2.03 & 467.32 & 497.69 & 559.96 \\
\hline TWN & 8.02 & 84.37 & 7.61 & 512.19 & 575.20 & 639.81 \\
\hline USA & 5.05 & 73.65 & 21.31 & 411.82 & 500.19 & 571.28 \\
\hline
\end{tabular}

Note: JPN is missing in this data due to lack of parental information 
Table 5: Class sizes in East Asia

\begin{tabular}{ccc}
\hline & \multicolumn{2}{c}{ Average class size } \\
\cline { 2 - 3 } Country & math & science \\
\hline Hong Kong & 37 & 39 \\
Indonesia & 45 & 44 \\
Japan & 36 & 36 \\
Korea & 42 & 43 \\
Malaysia & 38 & 38 \\
Philippines & 50 & 50 \\
Singapore & 37 & 37 \\
Thailand & 42 & 42 \\
Taiwan & 39 & 39 \\
USA & 26 & 26 \\
International Average & 31 & 31 \\
\hline
\end{tabular}

Source: based on TIMSS-R data 
Table 6: Relative Teacher's Pay

\begin{tabular}{lcccccc}
\hline & \multicolumn{3}{c}{ Teacher pay in US\$ (PPP) in 1992 } & \multicolumn{3}{c}{ ratio to per capita GDP } \\
\cline { 2 - 7 } & starting & 15 year & maximum & starting & 15 year & maximum \\
\hline United States & 22,171 & 34,213 & 37,771 & 0.88 & 1.36 & 1.51 \\
Japan & 17,958 & 32,277 & 45,251 & 0.94 & 1.69 & 2.37 \\
Hong Kong (China) & 20,973 & 40,289 & 57,786 & 1.07 & 2.06 & 2.96 \\
Taiwan (China) & 15,060 & 22,590 & 30,120 & 1.12 & 1.68 & 2.24 \\
\hline
\end{tabular}

Source: Nelson (1994) 
Table 7: Teacher qualification

\begin{tabular}{ccccccc}
\hline & \multicolumn{3}{c}{$\%$ of math students taught by } & \multicolumn{2}{c}{$\%$ of science students taught by } \\
& $\begin{array}{c}\text { Qualified } \\
\text { Teacher }\end{array}$ & $\begin{array}{c}\text { Certified } \\
\text { Teacher }\end{array}$ & $\begin{array}{c}\text { Qualified and } \\
\text { Certified }\end{array}$ & $\begin{array}{c}\text { Qualified } \\
\text { Teacher }\end{array}$ & $\begin{array}{c}\text { Certified } \\
\text { Teacher }\end{array}$ & $\begin{array}{c}\text { Qualified and } \\
\text { Certified }\end{array}$ \\
\hline Hong Kong & 68 & 78 & 56 & 84 & 84 & 73 \\
Indonesia & 92 & 47 & 42 & 63 & 94 & 59 \\
Japan & 93 & 100 & 93 & 86 & 100 & 86 \\
Korea & 97 & 99 & 97 & 93 & 98 & 91 \\
Malaysia & 72 & 89 & 65 & 74 & 96 & 72 \\
Philippines & 87 & 93 & 81 & 69 & 90 & 60 \\
Singapore & 84 & 100 & 84 & 94 & 100 & 94 \\
Thailand & 65 & 90 & 59 & 75 & 85 & 64 \\
Taiwan & 89 & 95 & 86 & 97 & 93 & 91 \\
USA & 61 & N/A & N/A & 71 & N/A & N/A \\
International Average & 84 & 85 & 73 & 82 & 86 & 71 \\
\hline
\end{tabular}

Note: qualified teacher means teachers who had math or science as the major area of study in their BA, MA, or teacher training program. Science data for Taiwan is for physics and chemistry. Science data for Indonesia is average for Biology and Physics

Source: based on TIMSS-R data 
Table 8: Determinants of math performance

\begin{tabular}{|c|c|c|c|c|c|c|c|c|c|c|}
\hline & \multicolumn{10}{|c|}{ Math } \\
\hline & $\mathrm{HKG}$ & IDN & JPN & KOR & MYS & PHL & SGP & THA & TWN & USA \\
\hline \multirow[t]{3}{*}{ boy } & 4.21 & $14^{* * *}$ & $-6.58 * * *$ & -2.24 & $-4.99 * * *$ & 1.42 & $-19.29 * * *$ & $11.19 * * *$ & -1.79 & 4.01 \\
\hline & $(2.63)$ & $(3.84)$ & $(2.45)$ & $(2.34)$ & (1.94) & (3.86) & $(2.72)$ & (3.19) & (2.4) & (2.7) \\
\hline & $8.25 * * *$ & 5.30 & $51.02 * * *$ & $44.31 * * *$ & $17.32 * * *$ & $9.48 * * *$ & $16.38 * * *$ & $5.08 * *$ & $24.12 * * *$ & $22.09 * * *$ \\
\hline mgood & $(1.85)$ & $(3.49)$ & (1.89) & $(1.77)$ & $(1.61)$ & $(3.32)$ & (2.09) & $(2.36)$ & $(2.12)$ & (2.16) \\
\hline \multirow[t]{2}{*}{ bsdmcmai } & $19.19 * * *$ & $26.09 * * *$ & $19.15 * * *$ & $24.01 * * *$ & $27.87 * * *$ & $18.41 * * *$ & $29.76 * * *$ & $22.34 * * *$ & $30.99 * * *$ & $28.27 * * *$ \\
\hline & $(2.41)$ & (4.39) & $(2.96)$ & (2.79) & (2.19) & (3.92) & $(3.15)$ & (3.61) & $(2.76)$ & (2.59) \\
\hline \multirow[t]{2}{*}{ bsbgedse } & $1.47^{*}$ & $4.06^{* * *}$ & $4.06^{* * *}$ & $7.02 * * *$ & $5.18 * * *$ & $5.8 * * *$ & $1.37^{*}$ & $5.91 * * *$ & $10.9 * * *$ & $4.24 * * *$ \\
\hline & $(0.84)$ & (1.3) & $(0.64)$ & $(0.65)$ & $(0.62)$ & $(1.27)$ & $(0.71)$ & $(0.89)$ & $(0.83)$ & (1.07) \\
\hline \multirow[t]{2}{*}{ bsdmpatm } & $15.15^{* * *}$ & $20.96^{* * *}$ & $9.15 * * *$ & -0.85 & $10.23 * * *$ & $19.86^{* * *}$ & -3.08 & $13.66^{* * *}$ & $11.45^{* * *}$ & $-5.39 * *$ \\
\hline & $(2.2)$ & (4.19) & $(2.36)$ & (2) & $(2.31)$ & $(3.71)$ & $(2.58)$ & $(3.08)$ & $(2.31)$ & $(2.35)$ \\
\hline \multirow{2}{*}{$\begin{array}{l}\text { Low home } \\
\text { resources }\end{array}$} & 0.05 & $-10.34 * *$ & & $-34.4 * * *$ & $-14.82 * * *$ & -3.71 & 1.98 & $-10.9 * * *$ & $-32.07 * * *$ & $-35.83 * * *$ \\
\hline & (3.04) & $(4.48)$ & & (5.1) & $(2.35)$ & $(4.5)$ & $(5.82)$ & $(3.57)$ & $(4.71)$ & (7.12) \\
\hline \multirow{2}{*}{$\begin{array}{l}\text { High home } \\
\text { resources }\end{array}$} & 8.50 & -9.98 & & $20.23 * * *$ & $31.79 * * *$ & -2.50 & -6.84 & $26.17 * *$ & $25.37 * * *$ & $28.5^{* * *}$ \\
\hline & $(7.36)$ & (12.03) & & $(2.83)$ & $(4.13)$ & $(9.17)$ & $(6.82)$ & $(10.6)$ & $(4.22)$ & (3.38) \\
\hline \multirow{2}{*}{$\begin{array}{l}\text { Teacher is } \\
\text { qualified }\end{array}$} & $30.79 * * *$ & -3.64 & $15.9^{* *}$ & $12.73 * *$ & -3.53 & $-75.09 * * *$ & $109.51^{* * *}$ & 8.44 & $-8.63 * *$ & \\
\hline & $(5.79)$ & (7.35) & $(7.22)$ & $(5.71)$ & $(2.57)$ & $(23.46)$ & (15.01) & (8.94) & $(3.87)$ & \\
\hline \multirow[t]{2}{*}{ class } & $-15.32 * * *$ & $14.1 * * *$ & 4.91 & 1.21 & $-3.99 * * *$ & $28.37 * * *$ & $87.58 * * *$ & $-4.34 *$ & $-12.43 * * *$ & $1.89 * * *$ \\
\hline & $(2.36)$ & $(2.03)$ & (12.53) & $(0.76)$ & $(0.82)$ & $(6.12)$ & (10.28) & $(2.33)$ & (1.9) & $(0.48)$ \\
\hline \multirow[t]{2}{*}{ city } & $34.74 * * *$ & $72.38 * * *$ & 6.44 & $15.14 * *$ & $30.91 * * *$ & $73.3 * * *$ & & $30.81 * * *$ & $28.61 * * *$ & $-30.49 * * *$ \\
\hline & $(9.75)$ & $(16.52)$ & $(5.26)$ & $(6.93)$ & $(2.76)$ & $(23.1)$ & & (10.15) & $(7.51)$ & $(5.22)$ \\
\hline \multirow[t]{2}{*}{ Auto1 } & 29.01 & $-58.14 *$ & 1.39 & -4.75 & $49.7 * * *$ & $-227.45 * * *$ & & $73.99 * * *$ & -4.17 & -12.72 \\
\hline & (19.24) & (30.13) & (5.33) & $(6.52)$ & $(6.34)$ & $(55.42)$ & & (15.59) & (7.48) & $(8.11)$ \\
\hline \multirow[t]{2}{*}{ Auto2 } & -4.94 & 34.54 & $-30.26^{* *}$ & -9.77 & $-23.06^{* * *}$ & -38.93 & & $72.48^{*}$ & 10.28 & -36.17 \\
\hline & (20.53) & (25.83) & $(13.73)$ & (6.04) & $(6.04)$ & (44.06) & & (40.43) & (6.3) & $(24.42)$ \\
\hline \multirow[t]{2}{*}{ Auto3 } & & $293.2 * * *$ & & -2.04 & $56.61 * * *$ & $110.88^{* * *}$ & & 19.37 & 3.19 & $-14.6^{* *}$ \\
\hline & & (27.09) & & $(5.16)$ & $(6.93)$ & (27.44) & & $(24.32)$ & $(6.66)$ & (7.16) \\
\hline \multirow[t]{2}{*}{ hiring } & $-23.33 * * *$ & $32.24 *$ & -0.85 & -7.48 & -3.38 & $-47.71 *$ & $-46.54 * *$ & 0.20 & 15.08 & $-33.05 * * *$ \\
\hline & $(5.22)$ & (19.5) & $(4.7)$ & $(4.89)$ & $(2.68)$ & $(25.62)$ & (19.64) & $(9.02)$ & (9.78) & $(9.48)$ \\
\hline \multirow[t]{2}{*}{ salaries } & $35.06^{* * *}$ & $-64.95 * * *$ & & $-8.07 *$ & $56.93 * * *$ & $56.45 * * *$ & & $-31.83 * * *$ & $-23.66^{*}$ & $-16.16^{* *}$ \\
\hline & $(5.68)$ & (15.84) & & $(4.68)$ & (5.14) & $(20.42)$ & & (8.88) & (12.96) & $(8.06)$ \\
\hline \multirow[t]{2}{*}{ Constant } & $529.82 * * *$ & $-377.44 * * *$ & 346.40 & $282.73 * * *$ & $411.01 * * *$ & $-535.2 * * *$ & $-1260.31 * * *$ & $403.76^{* * *}$ & $506.54 * * *$ & $300.88 * * *$ \\
\hline & $(45.28)$ & (79.1) & $(229.2)$ & (29.71) & $(26.12)$ & $(171.27)$ & (197.77) & $(48.91)$ & (43.19) & $(33.44)$ \\
\hline obs & 1922 & 2002 & 2833 & 4041 & 4555 & 1422 & 1591 & 1960 & 4801 & 2504 \\
\hline R-square & 0.5568 & 0.5098 & 0.3661 & 0.4244 & 0.4628 & 0.5573 & 0.8673 & 0.5364 & 0.4493 & 0.4938 \\
\hline
\end{tabular}

Notes: *** denotes significance at 1 percent, ** at 5 percent, * at 10 percent level. "Low home resources" and "High home resources" are dummies with "Medium home resources" as the reference point. These dummies were constructed by TIMSS using availability of educational materials available at home and parent's education. "Teacher is qualified" is a dummy based on whether teachers in each economy meet country-specific qualification criteria. auto1 is a dummy variable for "cannot choose textbook but content", auto2 is for "can choose textbook but not content", and auto3 is for "can choose textbook and content". The table includes only selected variables of interest. The actual specification includes more variables, including student family structure, self-assessment, peer effect, aspiration, homework policies, etc. 
Table 9: Determinants of science performance

\begin{tabular}{|c|c|c|c|c|c|c|c|c|c|c|}
\hline & \multicolumn{10}{|c|}{ Science } \\
\hline & $\mathrm{HKG}$ & IDN & JPN & KOR & MYS & PHL & SGP & THA & TWN & USA \\
\hline boy & $\begin{array}{c}8.31 * * * \\
(2.98)\end{array}$ & $\begin{array}{c}33.01 * * * \\
(3.17)\end{array}$ & $\begin{array}{c}3.14 \\
(2.54)\end{array}$ & $\begin{array}{c}11.44 * * * \\
(2.73)\end{array}$ & $\begin{array}{c}14.44 * * * \\
(2.19)\end{array}$ & $\begin{array}{c}2.57 \\
(4.55)\end{array}$ & $\begin{array}{l}-2.53 \\
(2.57)\end{array}$ & $\begin{array}{c}17.78 * * * \\
(2.73)\end{array}$ & $\begin{array}{c}10.7 * * * \\
(2.18)\end{array}$ & $\begin{array}{c}16.46^{* * *} \\
(3.68)\end{array}$ \\
\hline sgood & $\begin{array}{c}7.75^{* * *} \\
(2.14)\end{array}$ & $\begin{array}{c}0.36 \\
(3.28)\end{array}$ & $\begin{array}{c}40.47^{* * *} \\
(2.05)\end{array}$ & $\begin{array}{c}48.55^{* * *} \\
(2.12)\end{array}$ & $\begin{array}{c}9.54 * * * \\
(1.86)\end{array}$ & $\begin{array}{l}5.59 \\
(3.5)\end{array}$ & $\begin{array}{c}12.24 * * * \\
(1.37)\end{array}$ & $\begin{array}{c}2.94 \\
(2.21)\end{array}$ & $\begin{array}{c}13.97 * * * \\
(1.89)\end{array}$ & $\begin{array}{c}20.16^{* * *} \\
(3.16)\end{array}$ \\
\hline bsdscsai & $\begin{array}{c}15.95^{* * *} \\
(2.18)\end{array}$ & $\begin{array}{c}12.09 * * * \\
(3.29)\end{array}$ & $\begin{array}{c}19.75^{* * *} \\
(2.27)\end{array}$ & $\begin{array}{c}21.36^{* * *} \\
(2.81)\end{array}$ & $\begin{array}{c}22.63 * * * \\
(2.02)\end{array}$ & $\begin{array}{c}23.83 * * * \\
(3.72)\end{array}$ & $\begin{array}{c}22.25 * * * \\
(2.06)\end{array}$ & $\begin{array}{c}11.35^{* * *} \\
(2.02)\end{array}$ & $\begin{array}{c}16.4 * * * \\
(1.92)\end{array}$ & $\begin{array}{c}21.69^{* * *} \\
(3.12)\end{array}$ \\
\hline bsbgedse & $\begin{array}{c}4.85^{* * *} \\
(0.94)\end{array}$ & $\begin{array}{c}5.82^{* * *} \\
(1.07)\end{array}$ & $\begin{array}{c}5.79^{* * *} \\
(0.65)\end{array}$ & $\begin{array}{c}7.94 * * * \\
(0.77)\end{array}$ & $\begin{array}{c}2.13^{* * *} \\
(0.66)\end{array}$ & $\begin{array}{c}7.99 * * * \\
(1.38)\end{array}$ & $\begin{array}{c}-6.65^{* * *} \\
(0.6)\end{array}$ & $\begin{array}{c}7.92 * * * \\
(0.77)\end{array}$ & $\begin{array}{c}11.38^{* * *} \\
(0.75)\end{array}$ & $\begin{array}{c}5.16^{* * *} \\
(1.44)\end{array}$ \\
\hline bsdspats & $\begin{array}{c}7.88^{* * *} \\
(2.78)\end{array}$ & $\begin{array}{c}10.65 * * * \\
(3.35)\end{array}$ & $\begin{array}{c}7.73 * * * \\
(2.4)\end{array}$ & $\begin{array}{l}5.32 * * \\
(2.29)\end{array}$ & $\begin{array}{l}4.42^{*} \\
(2.58)\end{array}$ & $\begin{array}{c}31.22 * * * \\
(4.58)\end{array}$ & $\begin{array}{c}18.97 * * * \\
(2.69)\end{array}$ & $\begin{array}{l}4.89^{*} \\
(2.69)\end{array}$ & $\begin{array}{c}10.7 * * * \\
(2.24)\end{array}$ & $\begin{array}{c}11.16^{* * *} \\
(3.21)\end{array}$ \\
\hline $\begin{array}{l}\text { Low home } \\
\text { resources }\end{array}$ & $\begin{array}{l}-0.38 \\
(3.37)\end{array}$ & $\begin{array}{l}-1.09 \\
(3.52)\end{array}$ & & $\begin{array}{c}-37.19^{* * *} \\
(5.27)\end{array}$ & $\begin{array}{c}-21.35 * * * \\
(2.58)\end{array}$ & $\begin{array}{c}1.55 \\
(5.18)\end{array}$ & $\begin{array}{c}19.26^{* * *} \\
(4.21)\end{array}$ & $\begin{array}{l}-0.54 \\
(2.86)\end{array}$ & $\begin{array}{c}-24.61^{* * *} \\
(4.09)\end{array}$ & $\begin{array}{c}-31.15^{* * *} \\
(8.6)\end{array}$ \\
\hline $\begin{array}{l}\text { High home } \\
\text { resources }\end{array}$ & $\begin{array}{c}26.12 * * * \\
(8.3)\end{array}$ & $\begin{array}{c}4.46 \\
(11.14)\end{array}$ & & $\begin{array}{c}29.06^{* * *} \\
(3.34)\end{array}$ & $\begin{array}{c}35.69 * * * \\
(5)\end{array}$ & $\begin{array}{c}-1.47 \\
(11.77)\end{array}$ & $\begin{array}{l}12.37 \\
(7.71)\end{array}$ & $\begin{array}{c}20.65^{* * * *} \\
(7.39)\end{array}$ & $\begin{array}{c}23.98^{* * *} \\
(3.73)\end{array}$ & $\begin{array}{c}25.24 * * * \\
(4.48)\end{array}$ \\
\hline $\begin{array}{l}\text { Teacher is } \\
\text { qualified }\end{array}$ & $\begin{array}{c}13.14 * * * \\
(4.83)\end{array}$ & $\begin{array}{c}82.36^{* * *} \\
(20.68)\end{array}$ & $\begin{array}{c}3.17 \\
(4.52)\end{array}$ & $\begin{array}{c}4.02 \\
(5.36)\end{array}$ & $\begin{array}{c}14.94 * * * \\
(3.02)\end{array}$ & $\begin{array}{c}59.54 * * * \\
(11.02)\end{array}$ & $\begin{array}{c}-714.52^{* * *} \\
(64.44)\end{array}$ & $\begin{array}{l}9.02 * * \\
(4.47)\end{array}$ & $\begin{array}{c}8.10 \\
(6.83)\end{array}$ & \\
\hline class & $\begin{array}{l}-9.97 \\
(6.27)\end{array}$ & $\begin{array}{c}24.12 * * * \\
(5.45)\end{array}$ & $\begin{array}{l}5.98 * * \\
(2.79)\end{array}$ & $\begin{array}{c}1.03 \\
(0.88)\end{array}$ & $\begin{array}{c}-4.95 * * * \\
(1.79)\end{array}$ & $\begin{array}{c}-12.17 * * * \\
(3.92)\end{array}$ & $\begin{array}{c}232.81 * * * \\
(25.05)\end{array}$ & $\begin{array}{c}-3.54 * * * \\
(0.88)\end{array}$ & $\begin{array}{c}-10.67 * * * \\
(2.14)\end{array}$ & $\begin{array}{c}1.48 \\
(1.07)\end{array}$ \\
\hline city & $\begin{array}{l}19.54 \\
(13.8)\end{array}$ & $\begin{array}{l}-61.66^{*} \\
(32.05)\end{array}$ & $\begin{array}{c}-21.81 * * * \\
(5.97)\end{array}$ & $\begin{array}{l}-9.97 \\
(7.95)\end{array}$ & $\begin{array}{c}14.65^{* * *} \\
(3.3)\end{array}$ & $\begin{array}{c}49.47^{* *} \\
(20.98)\end{array}$ & & $\begin{array}{c}29.92 * * * \\
(8.39)\end{array}$ & $\begin{array}{c}20.87 * * * \\
(7.14)\end{array}$ & $\begin{array}{l}-12.65 \\
(9.09)\end{array}$ \\
\hline Auto1 & $\begin{array}{l}40.67^{*} \\
(24.62)\end{array}$ & $\begin{array}{c}-252.35^{* * *} \\
(42.72)\end{array}$ & $\begin{array}{c}4.60 \\
(5.22)\end{array}$ & $\begin{array}{l}-4.10 \\
(6.3)\end{array}$ & $\begin{array}{c}3.76 \\
(7.07)\end{array}$ & $\begin{array}{c}-258.13^{* * *} \\
(31.78)\end{array}$ & & $\begin{array}{l}18.34^{*} \\
(10.15)\end{array}$ & $\begin{array}{l}-5.23 \\
(6.71)\end{array}$ & $\begin{array}{l}-7.01 \\
(21.34)\end{array}$ \\
\hline Auto2 & $\begin{array}{c}-139.13 * * * \\
(32.55)\end{array}$ & & $\begin{array}{l}-13.40 \\
(12.52)\end{array}$ & $\begin{array}{c}0.80 \\
(8.43)\end{array}$ & $\begin{array}{c}8.45 \\
(6.75)\end{array}$ & $\begin{array}{c}142.7^{* * * *} \\
(23.62)\end{array}$ & $\begin{array}{c}1678.9^{* * *} \\
(81.93)\end{array}$ & $\begin{array}{c}15.96 \\
(16.69)\end{array}$ & $\begin{array}{c}0.31 \\
(5.77)\end{array}$ & $\begin{array}{c}73.4^{* * * *} \\
(24.46)\end{array}$ \\
\hline Auto3 & & $\begin{array}{l}-52.76 \\
(46.65)\end{array}$ & $\begin{array}{c}11.31 \\
(12.87)\end{array}$ & $\begin{array}{l}-0.69 \\
(6.73)\end{array}$ & $\begin{array}{c}47.24 * * * \\
(6.56)\end{array}$ & & & $\begin{array}{c}-20.15^{* *} \\
(10.27)\end{array}$ & $\begin{array}{c}2.28 \\
(6.45)\end{array}$ & $\begin{array}{l}-11.29 \\
(12.87)\end{array}$ \\
\hline hiring & $\begin{array}{l}-4.61 \\
(4.69)\end{array}$ & $\begin{array}{c}19.18 \\
(16.17)\end{array}$ & $\begin{array}{l}6.99 * \\
(3.91)\end{array}$ & $\begin{array}{l}-3.33 \\
(6.15)\end{array}$ & $\begin{array}{l}-5.7^{*} \\
(3.02)\end{array}$ & $\begin{array}{c}-35.87 * * * \\
(13.85)\end{array}$ & $\begin{array}{c}-642.8^{* * * *} \\
(23.6)\end{array}$ & $\begin{array}{c}25.3 * * * \\
(6.3)\end{array}$ & $\begin{array}{c}-23.12^{* * *} \\
(8.3)\end{array}$ & $\begin{array}{c}32.05^{* * *} \\
(8.47)\end{array}$ \\
\hline salaries & $\begin{array}{c}8.20 \\
(5.18)\end{array}$ & $\begin{array}{c}-213.43^{* * * *} \\
(43.13)\end{array}$ & $\begin{array}{c}-50.68 * * * \\
(14.64)\end{array}$ & $\begin{array}{c}-10.73^{*} \\
(5.74)\end{array}$ & $\begin{array}{c}19.4 * * * \\
(6.71)\end{array}$ & $\begin{array}{c}62.04 * * * \\
(16.18)\end{array}$ & & $\begin{array}{c}1.21 \\
(4.85)\end{array}$ & $\begin{array}{l}22.28^{*} \\
(11.49)\end{array}$ & $\begin{array}{c}39.24 * * * \\
(11.3)\end{array}$ \\
\hline constant & $\begin{array}{c}478.78 * * * \\
(119.65)\end{array}$ & $\begin{array}{c}-334.61^{*} \\
(176.5)\end{array}$ & $\begin{array}{c}238.8 * * * \\
(60.86)\end{array}$ & $\begin{array}{c}335.06^{* * *} \\
(33.13)\end{array}$ & $\begin{array}{c}413.16^{* * *} \\
(42.32)\end{array}$ & $\begin{array}{c}449.63 * * * \\
(117.2)\end{array}$ & $\begin{array}{c}-5487.77 * * * \\
(532.02)\end{array}$ & $\begin{array}{c}330.41 * * * \\
(31.86)\end{array}$ & $\begin{array}{c}589.2 * * * \\
(49.14)\end{array}$ & $\begin{array}{c}392.01 * * * \\
(43.52)\end{array}$ \\
\hline obs & 2004 & 1835 & 2609 & 3860 & 4501 & 1645 & 2451 & 2238 & 4646 & 2124 \\
\hline R-square & 0.4315 & 0.5008 & 0.3587 & 0.3884 & 0.3234 & 0.5604 & 0.8591 & 0.4846 & 0.3912 & 0.4229 \\
\hline
\end{tabular}

Notes: *** denotes significance at 1 percent, ${ }^{* *}$ at 5 percent, * at 10 percent level. "Low home resources" and "High home resources" are dummies with "Medium home resources" as the reference point. These dummies were constructed by TIMSS using availability of educational materials available at home and parent's education. "Teacher is qualified" is a dummy based on whether teachers in each economy meet country-specific qualification criteria. auto1 is a dummy variable for "cannot choose textbook but content", auto2 is for "can choose textbook but not content", and auto3 is for "can choose textbook and content". The table includes only selected variables of interest. The actual specification includes more variables, including student family structure, self-assessment, peer effect, aspiration, homework policies, etc. 
Table 10: Difference in Teaching Methods among Teachers with Different Degrees of Discretion and Autonomy

\begin{tabular}{|c|c|c|c|c|c|c|}
\hline \multirow[b]{2}{*}{ Economy } & \multicolumn{3}{|c|}{ Math } & \multicolumn{3}{|c|}{ Science } \\
\hline & $\begin{array}{l}\text { Can choose } \\
\text { content but } \\
\text { not textbook }\end{array}$ & $\begin{array}{l}\text { Can choose } \\
\text { textbook but } \\
\text { not content }\end{array}$ & $\begin{array}{l}\text { Can choose } \\
\text { textbook and } \\
\text { content }\end{array}$ & $\begin{array}{c}\text { Can choose } \\
\text { content but not } \\
\text { textbook }\end{array}$ & $\begin{array}{c}\text { Can choose } \\
\text { textbook but not } \\
\text { content }\end{array}$ & $\begin{array}{l}\text { Can choose } \\
\text { textbook and } \\
\text { content }\end{array}$ \\
\hline \multicolumn{7}{|l|}{ Hong Kong, } \\
\hline China & 0 & 0 & 0 & 0 & 0 & 0 \\
\hline Indonesia & 1 & 0 & 2 & 2 & 1 & 1 \\
\hline Japan & 1 & 1 & 2 & 0 & 0 & 0 \\
\hline Korea & 0 & 0 & 0 & 0 & 0 & 0 \\
\hline Malaysia & 2 & 3 & 2 & 1 & 0 & 1 \\
\hline Philippines & 0 & 2 & 1 & 1 & 1 & 1 \\
\hline Singapore & - & - & - & - & - & - \\
\hline Thailand & 1 & 0 & 0 & 1 & 0 & 1 \\
\hline Taiwan, China & 1 & 1 & 3 & 0 & 1 & 0 \\
\hline United States & 1 & 2 & 1 & 3 & 2 & 7 \\
\hline
\end{tabular}

- Not available.

Note: The number indicates the counts of statistically different responses given by teachers with partial and full autonomy compared to responses from teachers with no autonomy. The table is based on 25 different teaching methods or style recorded in the TIMSS survey. Data for Singapore are not available because very few teachers have autonomy.

Source: based on TIMSS data. 


\section{References}

Angrist, Joshua D., Eric Bettinger, Erik Bloom, Elizabeth M. King, and Michael Kremer. 2002. "Vouchers for Private Schooling in Colombia: Evidence From a Randomized Natural Experiment." American Economic Review 92(5): 1535-1558.

Angrist, Joshua D. and Jonathan Guryan. 2003. "Does Teacher Testing Raise Teacher Quality?

Evidence From State Certification Requirements." NBER Working Paper 9545. Cambridge, MA: National Bureau of Economic Research.

Angrist, Joshua D. and Victor Lavy. 1999. "Using Maimonides' Rule to Estimate the Effect of Class Size on Scholastic Achievement." Quarterly Journal of Economics 114(2): 533575.

-----. 2001. "Does Teacher Training Affect Pupil Learning? Evidence From Matched Comparisons in Jerusalem Public Schools." Journal of Labor Economics 19(2): 343-369.

Ballou, Dale. 2001. "Pay for Performance in Public and Private Schools." Economics of Education Review 20(1): 51-61.

Bedi, Arjun S. and Ashish Garg. 2000. "The Effectiveness of Private Versus Public Schools: The Case of Indonesia." Journal of Development Economics 61(2): 463-494.

Behrman, Jere R., Anil B. Deolalikar, and Lee-Ying Soon. 2002. "Promoting Effective Schooling Through Education Decentralization in Bangladesh, Indonesia, and Philippines." ERD Working Paper Series 23. Manila, Philippines: Asian Development Bank.

Benveniste, Luis, Martin Carnoy, and Richard Rothstein. 2003. All Else Equal: Are Public and Private Schools Different? New York: RoutledgeFalmer.

Bils, Mark and Peter J. Klenow. 2000. "Does Schooling Cause Growth?" American Economic Review 90(5): 1160-1183.

Cave, Peter. 2001. "Educational Reform in Japan in the 1990s: Individuality and Other Uncertainties." Comparative Education 37(2): 173-191.

Chapman, David W. 2000. "Trends in Educational Administration in Developing Asia." Educational Administration Quarterly 36(2): 283-308. 
Chuang, Yih chyi. 2000. "Human Capital, Exports, and Economic Growth: A Causality Analysis for Taiwan, 1952-1995." Review of International Economics 8(4): 712-720.

de la Fuente, Angel and Rafael Doménech. 2002. "Human Capital in Growth Regressions: How Much Difference Does Data Quality Make? An Update and Further Results." CEPR Discussion Paper Series 3587. London: Centre for Economic Policy Research.

Dessus, Sebastian. 2001. "Human Capital and Growth: the Recovered Role of Educational System." Policy Research Working Paper 2632. Washington, DC: World Bank.

Dimmock, Clive and Allan Walker. 1998. "Transforming Hong Kong's Schools: Trends and Emerging Issues." Journal of Educational Administration 36(5): 476-491.

Dolton, Peter. 2003. "A Review of 'The Economics of School Choice.'." Economic Journal 113(485): F167-F179.

Dolton, Peter and Anna Vignoles. 2000. "The Effects of School Quality on Pupil Outcomes: An Overview," in Hijke, Hans and Joan Muyksen (eds.), Education and Training in a Knowledge-Based Economy. New York: St. Martin's Press.

Dustmann, Christian, Najma Rajah, and Arthur van Soest. 2002. "Class Size, Education, and Wages." IZA Discussion Paper 501. Bonn, Germany: Institute for the Study of Labor (IZA).

Eberts, Randall W. and Kevin M. Hollenbeck. 2002. "Impact of Chater School Attendance on Student Achivement in Michigan." Upjohn Institute Staff Working Paper 02-080. Kalamazoo, MI: Upjon Institute of Employment Research.

Eskeland, Gunnar S. and Deon Filmer. 2002. "Autonomy, Particiaption, and Learning in Argentine School: Findings and Their Implications for Decentralization." Policy Research Working Paper 2776. Washington, DC: World Bank.

Fertig, Michael. 2003. "Educational Production, Endogenous Peer Group Formation and Class Composition: Evidence From the PISA 2000 Study." IZA DP 714. Bonn, Germany: Institute for the Study of Labor.

Glennerster, Howard. 2002. "United Kingdom Education, 1997-2001." Oxford Review of Economic Policy 18(2): 120-136.

Glewwe, Paul. 2002. "Schools and Skills in Developing Countries: Education Policies and Socioeconomic Outcomes." Journal of Economic Literature 40(2): 436-482. 
Glewwe, Paul, Nauman Ilias, and Michael Kremer. 2003. "Teacher Incentives." NBER Working Paper 9671. Cambridge, MA: National Bureau of Economic Research.

Hanushek, Eric A. 1986. "The Economics of Schooling: Production and Efficiency in Public Schools." Journal of Economic Literature 24(3): 1141-1177.

Hanushek, Eric A. 2002. "The Long Run Importance of School Quality." NBER Working Paper 9071. Cambridge, MA: National Bureau of Economic Research.

----. 2003. "The Failure of Input-Based Schooling Policies." Economic Journal 113(485): F64F98.

Hanushek, Eric A., John F. Kain, and Steven G. Rivkin. 1999. "Do Higher Salaries Buy Better Teachers?" NBER Working Paper 7082. Cambridge, MA: National Bureau of Economic Resesarch.

Hanushek, Eric A. and Dennis D. Kimko. 2000. "Schooling, Labor-Force Quality, and the Growth of Nations." American Economic Review 90(5): 1184-1208.

Hanushek, Eric A. and Javier A. Luque. 2002. "Efficiency and Equity in Schools Around the World." NBER Working Paper 8949. Cambridge, MA: National Bureau of Economic Research.

Hanushek, Eric A. and Steven G. Rivkin. 2001. "Does Public School Competition Affect Teacher Quality?" Presented at Economics of School Choice Conference, Islamorada, Florida, February 22, 2001.

Hanushek, Eric A., Steven G. Rivkin, and Lori L. Taylor. 1996. "Aggregation and the Estimated Effects of School Resources." Review of Economics and Statistics 78(4): 611-627.

Harmon, Colm, Hessel Oosterbeek, and Ian Walker. 2003. "The Returns to Education:

Microeconomics." Journal of Economic Surveys 17(2): 115-155.

Holmes, George M., Jeff DeSimone, and Nicholas G. Rupp. 2003. "Does School Choice Increase School Quality?" NBER Working Paper 9683. Cambridge, MA: National Bureau of Economic Research.

Hoxby, Caroline M. 2000a. "Does Competition Among Public Schools Benefit Students and Taxpayers?" American Economic Review 90(5): 1209-1238.

----. 2000b. "The Effects of Class Size on Student Achievement: New Evidence From

Population Variation." Quarterly Journal of Economics 115(4): 1239-1285. 
Jacob, Brian A. 2002. "Accountability, Incentives and Behavior: The Impact of High-Stakes Testing in the Chicago Public Schools." NBER Working Paper 8968. Cambridge, MA: National Bureau of Economic Research.

Jacob, Brian A. and Steven D. Levitt. 2003. "Catching Cheating Teachers: The Results of an Unusual Experiment in Implementing Theory." NBER Working Paper 9414. Cambridge, MA: National Bureau of Economic Research.

James, Estelle, Elizabeth M. King, and Ace Suryadi. 1996. "Finance, Management, and Costs of Public and Private Schools in Indonesia." Economics of Education Review 15(4): $387-$ 398.

Jepsen, Christopher and Steven G. Rivkin. 2002. "What Is the Tradeoff Between Smaller Classes and Teacher Quality?" NBER Working Paper 9205. Cambridge, MA: National Bureau of Economic Research.

Jimenez, Emmanuel and Yasuyuki Sawada. 2001. "Public for Private: The Relationship Between Public and Private School Enrollment in the Philippines." Economics of Education Review 20(4): 389-399.

King, Elizabeth M., Berk Ozler, and Laura B. Rawlings. 1999. "Nicaragua's School Autonomy Reform: Fact or Fiction?" Working Paper on Impact Evaluation of Education Reforms 19. Washington, DC: World Bank.

Krueger, Alan B. 1999. "Experimental Estimates of Education Production Functions." Quarterly Journal of Economics 114(2): 497-532.

-----. 2003. "Economic Considerations and Class Size." Econmic Journal 113(ㄴ5): F34-F63.

Krueger, Alan B. and Mikael Lindahl. 1999. "Education for Growth in Sweden and the World." Swedish Economic Policy Review 6(2): 289-339.

-----. 2001. "Education for Growth: Why and for Whom?" Journal of Economic Literature 39(4): 1101-1136.

Krueger, Alan B. and Pei Zhu. 2002. "Another Look at the New York City School Voucher Experiment." NBER Working Paper 9418. Cambridge, MA: National Bureau of Economic Research.

Lakdawalla, Darius. 2001. "The Declining Quality of Teachers." NBER Working Paper 8263. Cambridge, MA: National Bureau of Economic Research. 
Lavy, Victor. 2003. "Paying for Performance: The Effect of Teachers' Financial Incentives on Student's Scholastic Outcomes." CEPR Discussion Paper Series 3862. London: Centre for Economic Policy Research.

Lazear, Edward P. 2001. "Educational Production." Quarterly Journal of Economics 116(3): 777-803.

Lee, Jisoon. 2001. "Education Policy in Republic of Korea: Building Block or Stumbling Block?" World Bank Institute Working Paper 22648. Washington, DC: World Bank.

Lee, Jong-Wha and Robert J. Barro. 1997. "Schooling Quality in a Cross Section of Countries." NBER Working Paper 6198. Cambridge, MA: National Bureau of Economic Research. Levin, Henry M. 1998. "Educational Vouchers: Effectiveness, Choice, and Costs." Journal of Policy Analysis and Management 17(3): 373-392.

Muta, Hiromitsu. 2000. "Deregulation and Decentralization of Education in Japan." Journal of Educational Administration 38(5): 455-467.

Nelson, Howard F. 1994. "International Comparison of Teacher Salaries and Conditions of Employment," Developments in School Finance. National Center for Education Statistics, 111-127.

OECD. 1998. "Alternative Approach to Financing Lifelong Learning: Country Report of Korea." Paris: OECD.

Parry, Taryn Rounds. 1997. "Achieving Balance in Decentralization: A Case Study of Education Decentralization in Chile." World Development 25(2): 211-225.

Pritchett, Lant. 2001. "Where Has All the Education Gone?" World Bank Economic Review 15(3): 367-391.

Rouse, Cecilia Elena. 1998. "Private School Vouchers and Student Achievement: An Evaluation of the Milwaukee Parental Choice Program." Quarterly Journal of Economics 113(2): 553-602.

Sianesi, Barbara and John van Reenen. 2003. "The Returns to Education: Macroeconomics." Journal of Economic Surveys 17(2): 157-200.

"South Korea: Leaving Home" 2001. The Economist. March 31.

Stinebrickner, Todd R. 2002. "An Analysis of Occupational Change and Departure From the Labor Force: Evidence of the Reasons That Teachers Leave." Journal of Human Resources 37(1): 192-216. 
Strauss, Robert P., Lori R. Bowes, Mindy S. Marks, and Mark R. Plesko. 2000. "Improving Teacher Preparation and Selection: Lessons From the Pennsylvania Experience." Economics of Education Review 19(4): 387-415.

Temin, Peter. 2002. "Teacher Quality and the Future of America." NBER Working Paper 8898. Cambridge, MA: National Bureau of Economic Research.

Thailand Ministry of Education. 2000. Assessment on Education for All.

UNESCO. 2001. World Data on Education. Geneva:

Vegas, Emiliana. 2002. "School Choice, Student Performance, and Teacher and School Characteristics: The Chilean Case." Policy Research Working Paper 2833. Washington, DC: World Bank.

West, Martin R. and Ludger Woessmann. 2003. "Which School Systems Sort Weaker Students into Smaller Classes? International Evidence." IZA Discussion Paper 744. Bonn: Institute for the Study of Labor (IZA).

Witte, Johanna. 2000. "Education in Thailand After the Crisis: A Balancing Act Between Globalization and National Self-Contemplation." International Journal of Educational Development 20(3): 223-245.

Woessmann, Ludger. 2001. "New Evidence on the Missing Resource-Performance Link in Education." Kiel Working Paper 1051. Kiel: Kiel Institute of World Economics.

Woessmann, Ludger and Martin R. West. 2002. "Class-Size Effects in School Systems Around the World: Evidence From Between-Grade Variation in TIMSS." IZA Discussion Paper 485. Bonn: Institute for the Study of Labor (IZA).

Wood, Adrian and Kersti Berge. 1997. "Exporting Manufactures: Human Resources, Natural Resources, and Trade Policy." Journal of Development Studies 34(1): 35-59.

World Bank. 1993. The East Asian Miracle: Economic Growth and Public Policy. New York: Oxford University Press.

-----. 2000. Thailand Secondary Education for Employment. Washington, DC: World Bank. ----. 2002. World Development Indicators. Washington, DC: World Bank. 